\title{
深見克哉
}

九州大学有体物管理センター

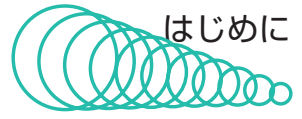

2017 年国会において, 名古屋議定書締結の承認を得て, 2017 年 8 月 20 日に名古屋議定書の締結に伴う行政措置「遺 伝資源の取得の機会及びその利用から生ずる利益の公正かつ 衡平な配分に関する指針 (ABS指針)」が施行された。これ に伴い, 海外からの遺伝資源入手, 特に発展途上国からの入 手に際し，遺伝資源提供国法令を十分に理解し，この指針に 従い国内の手続きを求められることになる.

今までに, 多くの記事において, 生物多様性条約（以後 $\mathrm{CBD}) \cdot$ 名古屋議定書（以後 NP） 及び食料及び農業に関す る植物遺伝資源に関する国際条約（以後ITPGRFA）の下, 遺伝資源の国際間における授受について，どのようなことを 遵守するのかなどの詳細が解説されている(1 3). これらの国 際条約や遺伝資源提供国の法令の縛り，そして日本の行政措 置に不安や重荷を感じ，発展途上国との先進的な研究の取り 組みに一歩踏み出すことを躊躇している研究者も多くいると 聞く，今回，そのようなことを踏まえて実例に則した視点 で，発展途上国から遺伝資源を入手する際に，どのようなこ とに注意して, どのような手順で入手すべきかについて, べ トナム，モンゴルなどの国の実例を基に，実際の手続きや入 手手順などを紹介し，遺伝資源提供国法令に従わず日本へ もってきた場合の問題についても考えたい. さらには, 基本 的に研究材料の授受では, 通常研究材料を入手する際に, 研 究材料移転契約（以後MTA）を締結するが，そのMTAは 発展途上国からの研究材料入手にも大きな役割を果たす。今 回，複数の遺伝資源提供国から入手した実績を基に，必要な 条項の意味を解説し, 最終的にどのような考え方で作成する のか, また, サンプル契約として実際に利用可能なMTA案 を紹介する。 これらの情報を活用して，今後の海外遺伝資源 利用に積極的にアクセスしていただきたい.

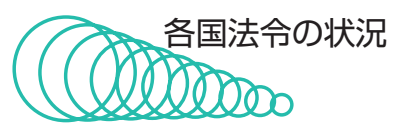

今年 2017 年 7 月 1 日にベトナムでは, 省令が改訂され発効 した ${ }^{(4)}$. 今回の改訂でベトナムの遺伝資源アクセスの詳細な
規定が定められ，利益配分の率とアクセスルールが明確に なったが，基本的な遺伝資源 $\mathrm{ABS}$ 考え方は，ほかのアジ アの国と概念的に類似している点が多いので, ベトナムの省 令を使って, 遺伝資源へのアクセス方法について説明する.

許可を得るための権限ある当局 (Competent Authority) は, 遺伝資源の種類で異なり, 農業関連の種子, 家畜, 水生 生物そして森林の植物（苗や種子など）は, Ministry of Agriculture and Rural Development, それ以外の遺伝資源は, Ministry of Natural Resources and Environmentとなる. 他 国においても，同様に遺伝資源の種類で権限ある当局が異な る場合が多いので留意する.

(研究者が個人でベトナムから遺伝資源を入手する場合) ベトナム省令 7 条に従い, 外国人（ベトナム人以外）は，い かなる目的でも遺伝資源へのアクセスをする場合，登録が必 要となる. 本省令 8 条に従い, (1) 遺伝資源の種類に伴い, 相応しい権限ある当局への登録，（2）ベトナムの提供者との 契約（遺伝資源を利用して得られる利益の分配 (BS) に関 する規定がされている必要がある)，（3）遺伝資源が存在し た（する）地方政府の契約内容確認と地方政府発行の証明 書，（4）（1）～(3）の書類をまとめて権限ある当局へ提出す る. ベトナムの微生物リソースセンター (Institute of Microbiology and Biotechnology (IMBT), Vietnam National University, Hanoi) ${ }^{(5)}$ への微生物へのアクセスの場合は，(3) の遺伝資源が存在した（する）地方政府は, IMBTで置き換 えられる。したがって, IMBTで保存されている微生物資源 ヘアクセスする場合, 研究者登録後, IMBT との提供契約 (MTA等) を締結し, 微生物を入手することになる.アク セスする遺伝資源の中で，国立公園内やアクセスが制限され ている遺伝資源（稀少生物等）については，(3) は地方政府 ではなく，それぞれを管轄する省の承認が必要となる。この 点は, 他国でも同じように制限された地域においては, 許可 を得る管轄が異なるので注意する.

(オンライン登録) アクセスする外国人の登録について, Webによるオンラインを Biodiversity Conservation Agency （BCA）に開設する予定であるが，まだオープンしていな い. インドネシアでは, 遺伝資源へアクセスする外国人の Webサイトによる登録システムが開設されており, インド ネシアの遺伝資源を利用する際には，まずこのサイトで登録 


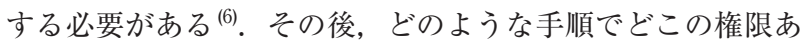
る当局と交渉すべきかについてのコンサルテーションが行わ れ，指示に従い進めていくためのシステムとなっている．他 国でもこのようなシステム導入を検討しており，同様の Web申請は，広まっていく可能性が高い。

(研究機関との共同研究に基づき遺伝資源の移転の場合) ベトナム省令 20 条 1 には, ベトナム人学生, 博士課程の学生 そしてベトナムの研究機関が, 研究のために海外へベトナム の遺伝資源を持ち出す手順が定められている．学生が海外一 ベトナムの遺伝資源を持ち出す場合には, 定型の申請書と受 入機関（海外研究機関等）の推薦状を付けて権限ある当局へ 申請を行うことで, 研究のために持ち出すことが可能にな る. ベトナムからの学生を大学に受け入れ, 研究のために遺 伝資源が持ち込まれる際には，これらの手続きを行ったかの 確認をすれば良い。また, 本省令 20 条 2 には, ベトナムの研 究機関が研究目的で海外の第三者へベトナムの遺伝資源を提 供する場合, ベトナムの研究機関（提供者）が定型の申請書 と受入機関の書面により受入同意書で権限ある当局へ申請す る. 当然，前述の特別な遺伝資源の場合には，提供者が事前 に管理当局（管轄の省）の許諾を得て，併せて申請をする． いずれにせよ, 研究目的で, 海外の研究機関へベトナムの遺 伝資源を提供する場合, ベトナム側の提供機関（提供者）や 個人（学生）による手続きをもって完了し, 受領者によるべ トナム政府への手続きは不要である。前述の微生物資源への アクセスの場合, IMBT と共同研究契約の下で微生物へアク セスするならば，IMBT と受領者との契約のみで，受領者に よるべトナム政府への手続きは不要となる。

(共同研究の下での入手) 多くの国で, 研究者が単独で海 外の遺伝資源へアクセスするより，その国の共同研究者を探 し, 共同研究の枠内（MOUの締結や共同研究契約の締結 後）で遺伝資源へのアクセスをすることにより，手続きが簡 便になる場合も多く，遺伝資源の取得の際に研究材料移転契 約（MTA）のみで，入手できる国も多い.

モンゴル*1では, 研究機関とのMOUが締結され, 共同研 究契約がされた後, 研究材料の移転には, MTAを締結する ことにより入手が可能である。 この場合，モンゴルの研究機 関がモンゴル環境省（フォーカルポイント）へ事前に契約内 容を打診し，ある程度の指導を受けて内容を修正後締結する のが手順である. 事前の研究者登録や, モンゴルのフォーカ ルポイントへのアクセスや相談は不要となる。 ただし，それ らの契約には，利用する遺伝資源から得られる利益，特に非 金銭的利益については，双方で合意された内容がMTAの中 に記載される必要がある。

このように，遺伝資源を入手する国の法令，適正な手順 を理解しておけば，特定の国を除いて，遺伝資源の入手は特 段難しいものではない，その際に締結される契約には，利益

*1 モンゴルでは，遺伝資源に関する法律は，Law on Flora（2011 改訂）を含むいくつかの法律と規制で構成されているが, 現在新 しい法律として, Law on Genetic Resourcesの準備を進めてお り, 今後記述の手順やルールが大きく変わる可能性が高い.
配分について文言や提供国に必要な手続きの責任の所在，つ まり提供者がきちんと法令を遵守し提供することを約束する 条項（後述）を入れて㧍くことで, 将来の問題に対する準備 に不足はないと思われる。

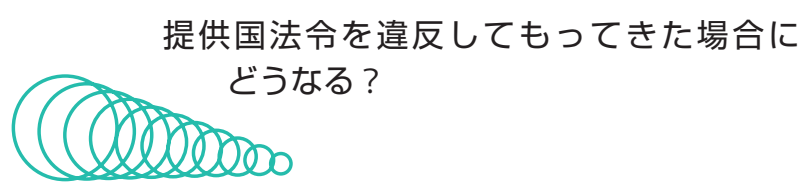

遺伝資源を入手する手続きや提供国の法令を理解してお けば，入手は容易であり，また，将来の問題に対する準備に 十分であると説明したが，その「将来の問題」とは何かにつ いて，少し考えてみたい。

（前提）まず，遺伝資源提供国の法令や適正な手順を， 知ってか, 知らずして, 結果的に不法に日本へ持ち出したと する。この場合, 日本一持ち込む際に日本国内法令（植物防 疫法, 動物検疫法, 薬機法やその他関連法）の遵守は当然 行っていることが前提である.

（遺伝資源提供国法令を遵守せず日本へ持ち込んだ場合） 法令を遵守せず日本へ持ち込んだ場合，何が問題になるだろ うか. 遺伝資源提供国法令に罰則規定が有った場合，持ち込 んだ当事者が日本に居れば，その罰則は適用されない。ただ し, 遺伝資源提供国法令を遵守せず持ち出した当事者が, 遺 伝資源提供国に再入国した際に，その法律が適用される場合 がある。それでは，違法に入手した遺伝資源を用いた結果を 論文に書いた場合，何か問題が発生するのかというと，その 学会のルールにしたがって記載すれば, 特段の問題はない. また, その遺伝資源から産業的価值が見いだされ, 特許出願 した場合も日本の特許法に触れることはない。白の特許や遺 伝資源を企業へライセンスした場合にも，民法で違法になる 可能性は低い.

（風評被害）何が問題になりうるかとすれば，違法に入手 した遺伝資源が財産的価值を生み, 大きな利益を得た場合, また，その事実が公になった場合に，遺伝資源提供国政府か らの外交ルートによるクレームや NGO など過激な団体に よるプロパガンダとその風評の問題である。つまり,もし $「 ○ ○$ 大学が違法に海外の遺伝資源を持ち出して, 特許出願 して，企業からロイヤリテイを得た」ということが，メディ アなどで取り沙汰された場合, その行為が日本で法的に問題 はなくとも，それは倫理的に受け入れられず，その研究者や 研究機関は, その風評から大きな打撃を受けることになる. 加えて，ライセンスを受けた企業にもその風評被害が広が り，企業イメージの失墜や売り上げの低下などの影響も少な くないと想像される.

遺伝資源提供国から不適切な入手と利用が日本において は法的に問題ないからといって, また, 研究が早く進むから といって不適切な手順での入手を推奨しているのではなく, もし不適切な入手を行った場合には, 実際にどのような被害 をだれが被るのか，を十分理解して扔く必要がある。このよ うな事態にならないためにも, 提供国法令があれば, 適切に 


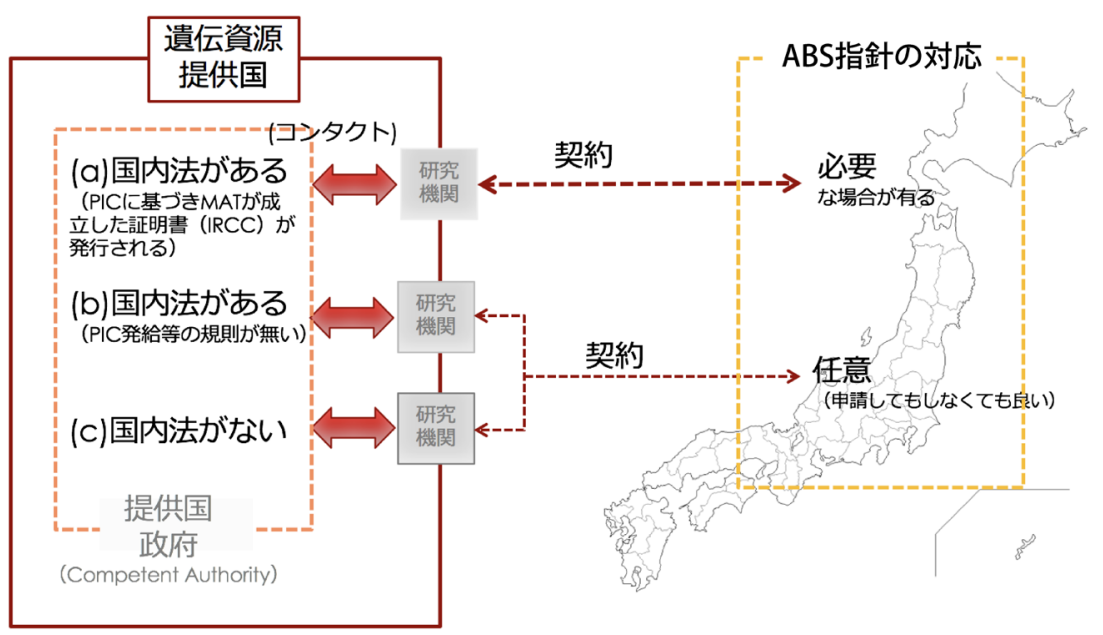

図1-共同研究者経由で入手

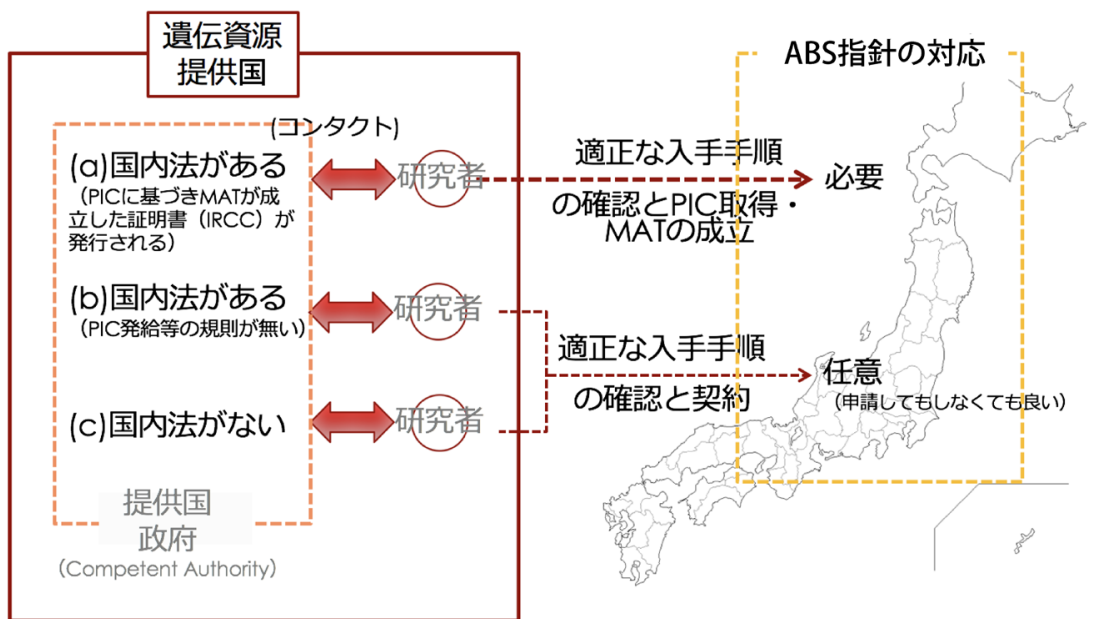

図2 - 研究者直接現地で探索

その手順で進め，提供国法令がない国ではメールなどを含む 遺伝資源入手の経緯や契約などの証拠を正しく保存すること が重要であると思う。今後, 国ごとに違う法令や, 遺伝資源 の種類, 用途の違いで, 大きく状況も変わる可能性があるた め, 研究者個人でというよりは, 組織的な対応や管理が必須 であると思われる(7).

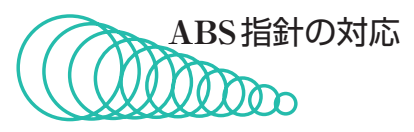

これまで, 適正な手順に従って海外の遺伝資源を入手す ることがいかに重要かについて述べた.この項では, 2017 年 8 月に発効した国内措置 (ABS 指針) の遵守（日本での入 手後の手続き) について, 遺伝資源提供国法令との関係も含 めて解説する.

ABS 指針は, 数年の専門家での議論や各団体からの意見 を配慮し, ABS指針を遵守することで, 研究開発に遅れが 出ないように, また, 多くの労力を割かずに, 遵守できるも のになっている.

（遺伝資源の適用範囲） ABS 指針は, 第 1 章第 3 に提供範
囲が定められ，名古屋議定書に定められていない遺伝資源等 が列記されている，核酸の塩基配列等の情報，人工合成核 酸, 遺伝の機能的谷を有しない生化学的化合物, ヒト遺伝 子, 名古屋議定書が日本で効力を生ずる以前（2017年 8 月 20 日以前）に得たもの, そして市場で購入したものを対象外と している.

（ABS指針に基づく報告）研究機関が $\mathrm{ABS}$ 指針で対応す べき事例は, 図 1,2 に示す。遺伝資源提供国において, 大学 等研究機関が遺伝資源をアクセスする場合, 研究者が直接現 地で遺伝資源を入手する場合と, 遺伝資源提供国の研究機関 との共同研究で入手する場合がある. どちらの場合でも, 遺 伝資源提供国法令があり，事前の情報に基づく同意（PIC） に基づき, 相互に合意した条件（MAT）が契約書等で明記 され締結された証明として, 許可証等を発行し, それを ABSクリアリングハウスに報告する規定（ABSクリアリン グハウスに報告され, そのホームページに掲載された場合に 国際遵守証明書 (Internationally Recognized Certificate of Compliance (IRCC)) とみなされる) がある場合に, 大学 等研究機関は, 遺伝資源の入手の際に, その手順に従い証明 書等を取得したことを, 環境省 $\mathrm{ABS}$ 空口に報告することに 
なる (図1a，図2a)，そのようなPIC, MATの手続きが定め られていない遺伝資源提供国法令であれば，もしくはそのよ うな法令がない国からの遺伝資源取得については, ABS指 針に基づく報告は，任意となる（図 $1 \mathrm{~b}, \mathrm{c}$, 図 $2 \mathrm{~b}, \mathrm{c}$ )。現時点 で，この図1a，図2aのような提供国法令を有している国は， インドを含む数カ国しかない.

（購入した遺伝資源）現地で遺伝資源を市場で購入して, 持ち帰ったものについては ABS指針でいう輸入者となり, $\mathrm{ABS}$ 指針に基づく報告は任意となる。しかし，遺伝資源提 供国法令が, この場合においても PIC およびMATを求め, 証明書の発給などを行えば，ABS指針に基づく報告は必要 となるため, 注意が必要である.

（ITPGRFA）植物遺伝資源は，ABS指針第3-2に，食料及 び農業のための植物遺伝資源に関する国際条約 (International Treaty on Plant Genetic Resources for Food and Agriculture (ITPGRFA)) で規定されるクロップリストに揭載 の植物遺伝資源は，ABS指針に適用しないとある，ITPGRFA の範囲にある植物遺伝資源の授受は, Standard MTA

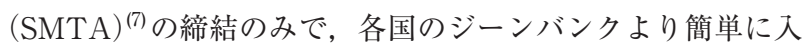
手可能であるが, ITPGRFAに扔ける植物遺伝資源の利用 は, “The Recipient undertakes that the Material shall be used or conserved only for the purposes of research, breeding and training for food and agriculture. (Standard MTA Article 6.1)” と限定されていることから, 食料及び農 業に関する利用以外の利用 “Such purposes shall not include chemical, pharmaceutical and/or other non-food/feed industrial uses. (Standard MTA Article 6.1)”については, 生物多様性条約/名古屋議定書の範囲に入ることから, その 遺伝資源提供国法令に従い，適正な入手手続きが必要な場合 や，ABS指針に基づく報告が必要な場合もあることに注意 を払う必要がある。

加えて, ABS指針と遺伝資源提供国法令遵守の関係につい て理解しておく必要があることは, ABS指針に記載のものが 対象外だから, 遺伝資源提供国の入手の際に手続きは不要で あるということではないということである。 あくまでも，遺 伝資源提供国の入手の際に，年の国の法令に定められている ことを遵守する．ただ，ABS指針の対象ではない入手につい ては,「ABS指針に基づく報告は必須ではない」だけのこと である.この点は混同しやすいので，注意すべきである.

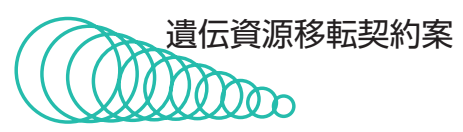

これまでアクセスについての遺伝資源提供国法令や日本 の $\mathrm{ABS}$ 指針対応について説明した。この項では，遺伝資源 入手のための契約，そして利益配分について説明する.

極めて多くの研究材料は, アメリカやヨーロッパの研究

*2 National Institutes of Health の略.

*3 Association of University Technology Managersの略で, アメ リカ産学連携の中核組織.
機関等とで研究推進のために授受のやり取りが行われてい る. その際に使われる研究材料移転契約 (Material Transfer Agreement (MTA)) は, NIH*2 や AUTM*3が作った雛 型がよく使われていて, 多くの研究機関で合意されているも のでもある。

（MTA基本的構成）その共通構成は，(1) 提供されるも のの定義と所有権，(2) 利用目的，(3) 提供される材料の利 用方法（第三者への提供，未改変物／派生物（derivatives） の取扱い, 研究終了後の残物の取扱い等), (4) 成果の取扱 (発表の方法や改変物（Modifications）の所有権）（5）提供 物の品質等の免責, (6) 提供物利用の際の法令遵守である. これらの条件は, 多くの研究機関で利用される条項であり, 多くの途上国でも用いている条項である。われわれは，海 外, 特に発展途上国から遺伝資源を入手するための MTAを 準備する際に，これらをフレームにして作成している.

(非金銭的利益) 発展途上国からの遺伝資源の入手の際に は, MATが必要であり, 遺伝資源の利用条件, 利益配分に ついて合意が必要となる，MATとは，契約を意味し，その 中に利益配分に関する条項が含まれていなければ，遺伝資源 提供の合意には至らない. 名古屋議定書のアネックスに非金 銭的利益の例が揭載されており，それを表 1 に転記した，大 学研究に扔いては, 非金銭的利益は主であり, いままでネ パール, タイ, ベトナム, モンゴル, カンボジアなどアジア の国の遺伝資源入手の際に，利益配分について議論してきた 結果，発展途上国が期待する非金銭的利益の多くは，表 1 (a)，(b)，(d)，(h)，(n) と（q）である. 通常のアメリ カ, ヨーロッパでの MTAには, 利益配分は明記しない場合 が多く, 発展途上国とのMTA と性質を異とする.

(契約の形式) 通常, 海外の研究機関と共同研究を行う場 合, MOUや共同研究契約を締結し, 共同研究を実施する. さらに, その研究で必要な遺伝資源を含む研究材料は別途締 結するMTAで移転されることが一般的である. しかし, 提 供国研究機関がMOUや共同研究契約締結を望まない場合, もしくは共同研究契約を結ぶほど大きな研究ではない場合, MTAのみで入手可能なことも多い.MOUや共同研究契約 の中に, 共同研究で実施する内容が協議され，(d) や (h) のキャパシティビルディング*4や (f) の研究技術の移転な どは記載されることが多いが, より具体的な遺伝資源の利用 条件については，MTAでその取扱いを定義することが多 い.まず，そのMTAがMOUや共同研究契約の下でなされ ていれば，その旨の記載があると，より MTAの位置づけが 明確になるので，望ましい。

(MTA 案) 発展途上国研究機関等から遺伝資源を入手す る際に，通常アメリカ・ヨーロッパなどと締結する契約より 具体的な遺伝資源の取扱いや利用後に得られた発明を含む成 果の取扱いについての記載が必要となる。最後に, 発展途上 国から遺伝資源を入手するためのMTA案全文を掲載した.

\footnotetext{
*4 能力構築と言い, この場合, 発展途上国等の研究機関の研究能 力を向上させるため, それに必要な能力の教育支援や研究の技術 移転などを行うことを言う。
} 


\section{表1 ・名古屋議定書アネックに記載の非金銭的利益例}

\begin{tabular}{|c|c|}
\hline \multicolumn{2}{|r|}{ Non-monetary bene ts may include, but not be limited to: } \\
\hline (a) & Sharing of research and development results; \\
\hline (b) & $\begin{array}{l}\text { Collaboration, cooperation and contribution in scienti c research and development programmes, particularly } \\
\text { biotechnological research activities, where possible in the Party providing genetic resources; }\end{array}$ \\
\hline (c) & Participation in product development; \\
\hline (d) & Collaboration, cooperation and contribution in education and training; \\
\hline (e) & Admittance to ex situ facilities of genetic resources and to databases; \\
\hline (f) & $\begin{array}{l}\text { Transfer to the provider of the genetic resources of knowledge and technology under fair and most favourable } \\
\text { terms, including on concessional and preferential terms where agreed, in particular, knowledge and technology } \\
\text { that make use of genetic resources, including biotechnology, or that are relevant to the conservation and } \\
\text { sustainable utilization of biological diversity; }\end{array}$ \\
\hline$(g)$ & Strengthening capacities for technology transfer; \\
\hline$(h)$ & Institutional capacity-building; \\
\hline (i) & $\begin{array}{l}\text { Human and material resources to strengthen the capacities for the administration and enforcement of access } \\
\text { regulations; }\end{array}$ \\
\hline$(j)$ & $\begin{array}{l}\text { Training related to genetic resources with the full participation of countries providing genetic resources, and } \\
\text { where possible, in such countries; }\end{array}$ \\
\hline$(k)$ & $\begin{array}{l}\text { Access to scientic information relevant to conservation and sustainable use of biological diversity, including } \\
\text { biological inventories and taxonomic studies; }\end{array}$ \\
\hline (I) & Contributions to the local economy; \\
\hline$(\mathrm{m})$ & $\begin{array}{l}\text { Research directed towards priority needs, such as health and food security, taking into account domestic uses of } \\
\text { genetic resources in the Party providing genetic resources; }\end{array}$ \\
\hline$(n)$ & $\begin{array}{l}\text { Institutional and professional relationships that can arise from an access and benefit-sharing agreement and } \\
\text { subsequent collaborative activities; }\end{array}$ \\
\hline (o) & Food and livelihood security benefits; \\
\hline$(p)$ & Social recognition; \\
\hline (q) & Joint ownership of relevant intellectual property rights. \\
\hline
\end{tabular}

本案Article 6に, 発表の際は遺伝資源の収集や成果に寄与 したことを配慮し，共著とすること，Article 7には，発明 を創出した場合は提供者とその取扱いを協議する，もしくは 特許は共有とすると明記している. Article 8においては, 改変物を創作した場合, 所有権の協議とさらなる研究の発展 のための第三者への提供の権限を定めるとした。これらの条 項は, 名古屋議定書に定める非金銭的利益を含む MATとし て十分な内容でもあると考えられるし，これ以上の過度な利 益配分を要求されたケースはなかった。しかし，各自MTA を締結する際は，本案の条項どおりに進めるというよりは， 研究を始める前に十分に提供者と受領者で, 想定される研究 の成果を議論し，それに従って，何を共有にすべきなのか, また，成果物の種類（図鑑や標本などの場合もある）などに よって, 利益配分の条件を臨機応変に定めることも肝要であ る.

（法令遵守義務）遺伝資源提供国に法令がない場合（図 1c，図2c）は，大型の研究プロジェクトでない，相手が MOUや共同研究契約を望まないなどの理由で，MTAのみ で遺伝資源を入手することが多い，その際，Article13に， 提供者の遺伝資源に関する法令遵守義務と受領者の保護を明 記している，遺伝資源提供国の詳細なルールなどは十分に把 握できない場合もあり，また，ベトナム国法令のように提供 者が提供国に手続きをする場合が多く，この条項により，万 が一NGOなどに「不正アクセスだ」などのクレームがあっ
たとしても，この契約が楯となる期待は高い.

今回の添付 MTA案は, いままでいくつかの発展途上国の 研究機関や研究者の合意を得て, 種々の遺伝資源を入手した 経験があるものである。しかし，前述のと打り，遺伝資源の 種類，用途などにより，不要な条項や加筆すべき条件などが 場合により発生するため，適宜修正を加えて利用していただ きたい，これを用いて，迅速な遺伝資源の授受の一助になれ ば幸いである.

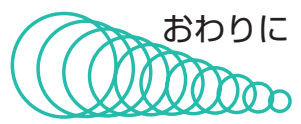

国際条約や遺伝資源提供国法令の多様性，外国法令拈よ び日本のABS指針との関係が複雑で，遺伝資源の種類に よっても状況が異なることから，多少の混乱が現場で発生し ている．今回，これらのことを正確に説明すれば，より多く の枝葉について紹介しないといけないが，読者が遭難する可 能性もあり，できるだけ単純に本質的な部分を理解してもら うために，荒っぽい解説や簡単な説明に終始した．またここ れから，名古屋議定書を締結した国では，それぞれの法令を 新しく発効したり, 改定したりし, 状況は日々変わってい く，実際に，海外の遺伝資源を入手する際に，紹介した事例 と全く違った状況を経験するかもしれないが，MTAの基本 構造は大きく変わることはない。まず，このMTAを基本 
に，適正に入手する努力をしていただければと思う．

本稿を読んでいただいたことで, ほかの解説書でより深く理

解をしていただくきっかけとなり，海外の遺伝資源の適正な

入手とそれを利用した研究が推進されることを願う。

\section{- 契約書案}

\section{Material Transfer Agreement \\ Between \\ University, Country (“PROVIDER”) \\ And \\ $\triangle \triangle$ University, Japan (“RECIPIENT”)}

RECIPIENT requests the MATERIAL [name of materials], under the JOINT RESEARCH AND DEVELOPMENT AGREEMENT between $\triangle \triangle$ University and $\square \square$ University dated on dd MM YY, and PROVIDER asks that RECIPIENT agrees and RECIPIENT scientist acknowledges to the following terms and conditions and other terms and conditions as provided in Attachment 1 in this Material Transfer Agreement (this "Agreement"). (PROVIDER and RECIPIENT may be referred to individually as the "Party" and jointly as the "Parties"):

1. The MATERIAL is made available as a service to the research community.

2. The MATERIAL IS NOT FOR USE IN HUMAN SUBJECTS.

3. The MATERIAL will be used for the Collaborative Research purposes defined in the JOINT RESEARCH AND DEVELOPMENT AGREEMENT (the "RESEARCH”) only. PROVIDER retains all right, title and interest in the MATERIAL. Any right of any intellectual property owned by or licensed to PROVIDER is not licensed or granted to RECIPIENT by this Agreement, without prior written consent of PROVIDER.

4. The MATERIAL will not be further distributed to others who are not under RECIPIENT SCIENTIST's direct supervision without PROVIDER's written consent. RECIPIENT shall refer any request for the MATERIAL to PROVIDER.

5. RECIPIENT will only provide the MATERIAL to Recipient employees or students who need to use the MATERIAL for conduct of the RESEARCH. RECIPIENT and RECIPIENT SCIENTIST shall be responsible for ensuring that all such persons comply with this Agreement.

6. In the event that PROVIDER intends to publish and/or present, in the form of papers, presentations at academic conferences and otherwise the Result of the RESEARCH conducted by RECIPIENT using the MATERIAL, authorship shall be shared by both RECIPIENT and PROVIDER Scientists.

7. If RECIPIENT creates any Inventions in connection with the MATERIAL, RECIPIENT shall without delay notify PROVIDER and consult with PROVIDER with regard to the handling of such inventions. or (In principle, the right to obtain patents on the results from the RESEARCH shall be owned equally by PROVIDER and RECIPIENT.)

8. If RECIPIENT creates modifications, which contain/incorporate the MATERIAL, RECIPIENT agrees, in ad- vance of the use thereof, to negotiate in good faith with PROVIDER to establish the right of ownership and further transfer thereof to others.

9. Any MATERIAL delivered pursuant to this Agreement is understood to be experimental in nature and may have hazardous properties. PROVIDER MAKES NO REPRESENTATIONS AND EXTENDS NO WARRANTIES OF ANY KIND, EITHER EXPRESSED OR IMPLIED. THERE ARE NO EXPRESS OR IMPLIED WARRANTIES OF MERCHANTABILITY OR FITNESS FOR A PARTICULAR PURPOSE, OR THAT THE USE OF THE MATERIAL WILL NOT INFRINGE ANY PATENT, COPYRIGHT, TRADEMARK, OR OTHER PROPRIETARY RIGHT, Unless prohibited by law, RECIPIENT assumes all liability for claims for damages against it and PROVIDER by third parties which may arise from the use, storage of disposal of the MATERIAL under this Agreement.

10. RECIPIENT agrees to use the MATERIAL in compliance with all applicable statutes and regulations.

11. The MATERIAL is provided with a nominal transmittal fee solely to reimburse PROVIDER for its preparation and distribution costs.

12. In the event that RECIPIENT discontinues or terminates use of the MATERIAL, RECIPIENT shall promptly give written notice to that effect to PROVIDER and shall be responsible for promptly disposing of all the remaining MATERIAL in its possession and will provide prompt written notice to PROVIDER regarding such disposal.

13. In providing the MATERIAL, PROVIDER shall conform to the laws, policies, rules and regulations concerning the biological resources in PROVIDER's country (collectively the "Rules"). PROVIDER shall be solely responsible for any deviation from any of the Rules in any aspect including collection and transfer of the MATERIAL. RECIPIENT shall bear no responsibility for any deviation or contravention from any Rules. PROVIDER shall indemnify and hold harmless RECIPIENT and its officers, employees, students from any claims arising in connection with any deviation or contravention from any Rules.

14. Any dispute related to this Agreement shall be settled by the law of PROVIDER's COUNTRY without reference to conflicts of law principles.

PROVIDER, RECIPIENT and RECIPIENT Scientists must sign both copies of this letter. RECIPIENT shall send one signed copy to PROVIDER. PROVIDER will then send the MATERIAL to RECIPIENT upon receiving the signed copy.

\section{PROVIDER IMFORMATION and AUTHORIZED SIGNA-} $\underline{\text { TURE }}$

PROVIDER Scientist (PI):

PROVIDER Organization:

Address:

Name of Authorized Official:

Title of Authorized Official:

Certification of Authorized Official: I have read and understood the conditions outlined in this agreement and I agree to send 
the MATERIALS.

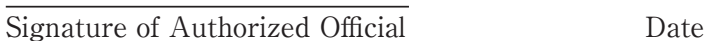

RECIPIENT INFORMATION and AUTHORIZED SIGNATURE

RECIPIENT Scientist (PI):

RECIPIENT Organization:

Address:

Name of Authorized Official:

Title of Authorized Official:

$\overline{\text { Signature of Authorized Official }}$

Date

Certification of RECIPIENT Scientist: I have read and understood the conditions outlined in this Agreement and I agree to abide by them in the receipt and use of the MATERIAL.

RECIPIENT Scientist

Date

略称：ABS: Access and Benefit Sharing, AUTM: Association of University Technology Managers, BCA: Biodiversity Conservation Agency, CBD: Convention on Biological Diversity, IMBT: Institute of Microbiology and BioTechnology, IRCC: Internationally Recognized Certificate of Compliance, ITPGRFA: International Treaty on Plant Genetic Resources for Food and Agriculture, MAT: Mutually Agreed Terms, MOU: Memorandum of Understanding, MTA: Material Transfer Agreement, NGO: Non-Governmental Organization, NIH: National Institutes of Health, NP: Nagoya Protocol, PIC: Prior Informed Consent, SMTA: Standard Material Transfer Agreement
文献

1) 井上 歩：バイオサイエンスとインダストリー， 75, 264 (2017).

2) 磯崎博司 : 地球環境学, 12, 1 (2017).

3) 森岡 一 : 一般社団法人日本国際知的財産保護協会月報, 61, 954 (2016).

4) ABSCH: Country Profiles, Vietnam, https://absch.cbd. int/countries/vn

5) IMBT: http://imbt.vnu.edu.vn/en/

6) RISTEK: Indonesia: Foreign Research Permit (Online Application), http://frp.ristek.go.id

7) 深見克哉: 研究イノベーション学会誌, 32, 185 (2017).

8) FAO: SMTA, http://www.fao.org/3/a-bc083e.pdf

\section{プロフィール}

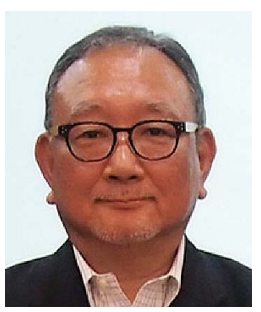

深見 克哉 (Katsuya FUKAMI)

<略歴 $>1984$ 年九州大学理学部を卒業し, 旭化成工業株式会社に入社／日本たばこ 产業株式会社を経て / 2004年九州大学知 的財産本部に入職 $/ 2009$ 年有体物管理セ ンターへ異動. 現在に至るく研究テーマ と抱負>成果有体物の財産権の運用など の研究推進に資する管理方法の開発, 海 外伝統的知識を活用した産学連携推進, 国内の伝統的知識や遺伝資源の保全 $<$ 趣 味 $>$ 仕事 $<$ 所属研究センターホームペー ジ>https://mmc-u.jp

Copyright (C) 2018 公益社団法人日本農芸化学会 DOI: 10.1271/kagakutoseibutsu.56.52 